\title{
Human Capital Development for Agribusiness in Higher Education: The Experience of Taiwan
}

\author{
Wen-Chi Huang
}

\author{
University of Science and Technology \\ *Corresponding author. Email: wenchi@g4e.npust.edu.tw
}

\begin{abstract}
Many countries face the problems of aging farming population. Solutions include reducing labor needs and improving managerial efficiency through formal education and technical training or extension services. Higher education institutions need to show that they engage in knowledge creation and sharing, assure that they provide high quality education yet down to earth applicability by linking to the grass root level need of agribusiness and its related businesses for now and onto the future. The agricultural industry moves fast in the new era of knowledge-based economy, in particular, Taiwan government is promoting "Agriculture 4.0" in which the development and application of smart agriculture in production technology; building agricultural productivity knowledge and service support systems, integrating IoT technology, creating diversified digital agriculture and providing convenient services, value chain integration applications. It creates tremendous opportunities for agribusiness and its supporting services. Yet, it also posts challenges to educational institutions to be flexible and innovative. Assessment of current resources and innovativeness in the prevision of business education to answer to the calls is vital. The purpose of the talk is to share selective initiatives innovative approaches to enhance education for the higher educational institution for agribusiness management.
\end{abstract}

\section{Keywords: Smart Agriculture, Higher Education, Human Resource Development, Human Capital,} Positioning

\section{INTRODUCTION}

Many countries face the problems of aging farming population. Taiwan is no exception. The 2015 census reports the average age of farmers in Taiwan had reached 63.5 years old [1], and in Japan it was 66.4 [2]. Proposed solutions include reducing labor needs and improving managerial efficiency through formal education and technical training or extension services, adapting smart solutions in farm management is one of new directions [3].

However, the severity of the problem is not only at the ground level for the practitioners in the field, but challenges to the whole agribusiness and food sector [4].The importance for high quality intellectual capital on the performance of agribusiness has been well documented. A recent article by Scafarto et al. [5] points out that out of the four components of intellectual capital which include human capital, relationship, innovation and process; that for agro-biotech companies and agrochemical companies, the human capital is not directly contributing for firm performance, but it has a moderating role for innovation.

Higher education institutions need to show that they engage in knowledge creation and sharing, assure that they provide high quality education yet down to earth applicability by linking to the grass root level need of agribusiness and its related businesses for now and onto the future. The agricultural industry moves fast in the new era of knowledge-based economy, in particular, Taiwan government is promoting "Agriculture 4.0" in which the development and application of smart agriculture in production technology; building agricultural productivity knowledge and service support systems, integrating IoT technology, creating diversified digital agriculture and providing convenient services, value chain integration applications. In a recently commissioned research by the National Development Council of Taiwan, the researchers 
identified the job skills need for the new agriculture [6]. It creates tremendous opportunities for agribusiness and its supporting services. Yet, it also posts challenges to higher educational institutions to be flexible and innovative.

Assessment of current resources and innovativeness in the prevision of business education to answer to the calls is vital. The purpose of the talk is to share selective initiatives innovative approaches to enhance education for the higher educational institution for agribusiness management.

\section{AGRIBUSINESS EDUCATION IN TAIWAN: HISTORY}

The National Pingtung University of Science and Technology (NPUST) was established in 1924 as a training institute for professionals working in animal husbandry and veterinarians. The university after several changes and repositions, it became a comprehensive university in 1997. Currently, the mission of the university remains as a "professional, international and holistic qualities as an internationally distinguished university." The university houses six colleges: agriculture, veterinary, engineering, management, liberal arts and social sciences, and international college. The Department of Agribusiness Management, housed in College of Management, is the one and only department in Taiwan that focuses on training talents for agribusinesses. Compared to the history of the university, it is a much younger disciplinary area which was established in 1975 under the name of agricultural economics. The department changed its name from agricultural economics to be more focus on managing agribusinesses in 1991. It is a truly an interdisciplinary program that it strives to serve the need of the agricultural sector in the modernization of the industry by taking in agricultural vocational high school graduates as the main components for the undergraduate pool of students in order to serve the national development goal of the nation.

Over the years, the department started to offer curriculum for international students either as short-term exchange or fully registered in the special programs designed for international students. The mini history of such changes is shown in Figure 1. The first batch that was benefited from the program is the elite special class for students from The Gambia. The project was implemented by the only English taught program on campus, the Department of Tropical Agriculture and International Cooperation, there were eight students enrolled in the agribusiness management sub program and their professional trainings in the management related field for much of the four-year period was designed and implement by all member of the faculty of the agribusiness management department with some support from other departments in the management field. With the success of the program, the department initiated a double degree program with faculty of agricultural economics with the Brawijaya University, then a special all-English taught international program at master level has been created for agribusiness management major in the international college.
Furthermore, the newest program for Chinese-speaking community in Malaysia has been initiated to serve the needs for on-the-job agribusiness managers and leaders who were mainly alumni of the university..

\section{INNOVATION IN EDUCATION: CURRICULUM TO INCLUDE FIELD PRACTICES IN THE REAL WORLD}

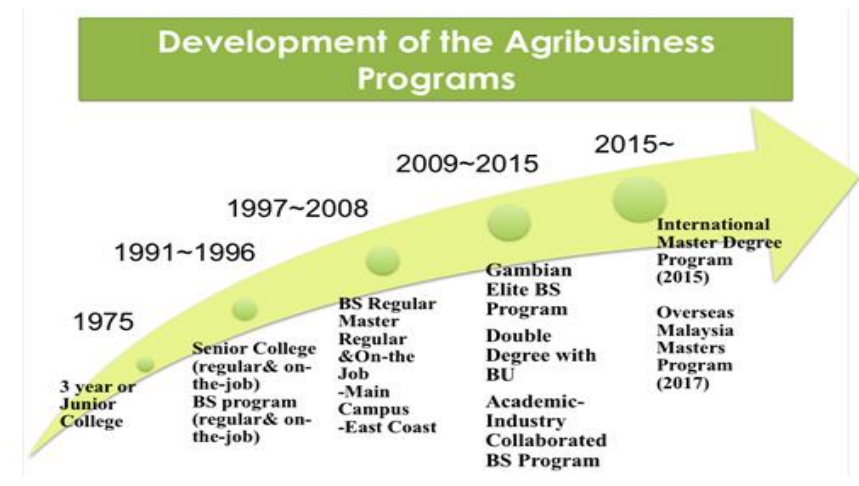

Figure 1 Development of the Agribusiness Management Program at National Pingtung University of Science and Technology, Taiwan

There are several changes implemented over the year. To increase the training on practical application, the students were requested to complete a practical research report under the supervision of their advisor before graduation. While implementing the international mobility projects, theses is a need to connect to existing resources through faculty member, university and alumni.

The mechanism for curriculum change involves a regular four-year cycle of assessment of the development needs, involving industry, academia, government, and alumni representative in the development meeting as well as course meeting at the department level. The members from outside of the university were generated through department meeting to nominate and approach the identified personal to join as formal seats for the respective meeting. The committee will give general guideline at the development meeting and give specific recommendations to the current courses structure and as well as specific courses to be included or excluded.

For other project-based program such as the Gambian special class, the Academic-Industry collaborated project for the undergraduate students, and others were discussed at the department meetings and then submission to the Ministry of Education for the competitive project fund. The upon approved of the program, the curriculum design will have to pass through the internal process of the three-tier course meeting system at the university from department, college, and the university wide approval before implementation. 
Students' professional engagements take two broad categories of approaches: in-bound and out-bound. The inbound approaches including practical courses and coteaching with professional speciality from the industry. Each course is allowed to have a maximum of one-thirds of the classroom activities. To ensure the quality of the co-teachers in such design, the application for courses to involve the professionals need to pass the department meetings and the priority set at the meeting.

The out-bound approaches include organize field trips in the course, internships (summer internship for graduate students, and a-semester-long internship for undergraduate students), and through focused research projects and facultysupervised oversee studies as exchange students or overseas internships. [7] documented the department's engagement in overseas internship program through project supported by the Ministry of Education. Over the years, the students have been deployed to the Philippines, Indonesia, Malaysia, Thailand, Korea, and Japan. The collaborators include regional non-government organizations such as Asia Partnership for Human Resource Management in Rural Area (AsiaDHRRA), regional farmers' organization such as Asian Farmers Association for Sustainable Rural Development (AFA), as well as its member organization in respective countries. The longest standing overseas internship partner is an organic farmers organization in Japan (Ainoukai), which is a member of AFA. Other partners include sister universities of NPUST and alumni of the agribusiness programs.

For undergraduate students' semester off-campus long internship is a 9 credits full time training; the department initiates the first planning meetings about 10 months before the implementation. The students should identify advisor at least 8 months before the internship, and contract among student (with parental consents), university, and the recipient agribusiness institute (include profit and nonprofit organization). The students need to finish 18 weeks of internship training, write weekly training report and submit to the designated website for interns, and they need to report back to university through a presentation sharing during midterm and final exam week. An internship exposition has been held along side with the final presentation. During the 18 weeks, the supervisor needs to conduct site visits at least twice and numbers contacts through social media or other platform for constant contacts. Matters arise during the visits as well as after concluding the internship training, the department holds evaluation and reflection meetings to conclude the internship project annually.

Taiwan government is promoting "Agriculture 4.0" in which the development and application of smart agriculture in production technology; building agricultural productivity knowledge and service support systems, integrating IoT technology, creating diversified digital agriculture and providing convenient services, value chain integration applications. It creates tremendous opportunities for agribusiness and its supporting services. It has been projected for the next 10 years, the new agriculture calls for human capital in the domain of the whole value chain in agribusiness to be able to adapt the new digital technology; the contents include the capability of using AI-IoT in smart agriculture [8]. Yet, it also posts challenges to educational institutions to be flexible and innovative. To answer the quest for the Agricultural 4.0, the department is now carrying out a 10 credits mini program to enhance the student's ability to use smart technology and data analytics for the on the farm and for marketing purposes. Some faculty members of the department have long involved in agricultural extension services and was members of the national program to train farmers to use management information systems designed for farms and farming groups for the nation. Over the years, such advancement has been tremendous. With the support of the project, the department started deploying faculty members to participate training programs, faculty-list to companies that design and implement the software used by agribusinesses (farms and agricultural cooperatives). The project also aims to incorporate the leaning and sharing from the agribusiness and its supporting industry to include in the traditional courses.

\section{CONCLUSION}

There are several changes implemented over the year. To increase the training on practical application, the students were requested to complete a practical research report under the supervision of their advisor before graduation. While implementing the international mobility projects, theses is a need to connect to existing resources through faculty member, university and alumni.

The mechanism for curriculum change involves a regular four-year cycle of assessment of the development needs, involving industry, academia, government, and alumni representative in the development meeting as well as course meeting at the department level. The members from outside of the university were generated through department meeting to nominate and approach the identified personal to join as formal seats for the respective meeting. The committee will give general guideline at the development meeting and give specific recommendations to the current courses structure and as well as specific courses to be included or excluded.

For other project-based program such as the Gambian special class, the Academic-Industry collaborated project for the undergraduate students, and others were discussed at the department meetings and then submission to the Ministry of Education for the competitive project fund. The upon approved of the program, the curriculum design will have to pass through the internal process of the three-tier course meeting system at the university from department, college, and the university wide approval before implementation.

Students' professional engagements take two broad categories of approaches: in-bound and out-bound. The inbound approaches including practical courses and coteaching with professional speciality from the industry. Each course is allowed to have a maximum of one-thirds of the classroom activities. To ensure the quality of the co-teachers 
in such design, the application for courses to involve the professionals need to pass the department meetings and the priority set at the meeting.

The out-bound approaches include organize field trips in the course, internships (summer internship for graduate students, and a-semester-long internship for undergraduate students), and through focused research projects and facultysupervised oversee studies as exchange students or overseas internships. [7] documented the department's engagement in overseas internship program through project supported by the Ministry of Education. Over the years, the students have been deployed to the Philippines, Indonesia, Malaysia, Thailand, Korea, and Japan. The collaborators include regional non-government organizations such as Asia Partnership for Human Resource Management in Rural Area (AsiaDHRRA), regional farmers' organization such as Asian Farmers Association for Sustainable Rural Development (AFA), as well as its member organization in respective countries. The longest standing overseas internship partner is an organic farmers organization in Japan (Ainoukai), which is a member of AFA. Other partners include sister universities of NPUST and alumni of the agribusiness programs.

For undergraduate students' semester off-campus long internship is a 9 credits full time training; the department initiates the first planning meetings about 10 months before the implementation. The students should identify advisor at least 8 months before the internship, and contract among student (with parental consents), university, and the recipient agribusiness institute (include profit and nonprofit organization). The students need to finish 18 weeks of internship training, write weekly training report and submit to the designated website for interns, and they need to report back to university through a presentation sharing during midterm and final exam week. An internship exposition has been held along side with the final presentation. During the 18 weeks, the supervisor needs to conduct site visits at least twice and numbers contacts through social media or other platform for constant contacts. Matters arise during the visits as well as after concluding the internship training, the department holds evaluation and reflection meetings to conclude the internship project annually.

Taiwan government is promoting "Agriculture 4.0" in which the development and application of smart agriculture in production technology; building agricultural productivity knowledge and service support systems, integrating IoT technology, creating diversified digital agriculture and providing convenient services, value chain integration applications. It creates tremendous opportunities for agribusiness and its supporting services. It has been projected for the next 10 years, the new agriculture calls for human capital in the domain of the whole value chain in agribusiness to be able to adapt the new digital technology; the contents include the capability of using AI-IoT in smart agriculture [8]. Yet, it also posts challenges to educational institutions to be flexible and innovative. To answer the quest for the Agricultural 4.0, the department is now carrying out a 10 credits mini program to enhance the student's ability to use smart technology and data analytics for the on the farm and for marketing purposes. Some faculty members of the department have long involved in agricultural extension services and was members of the national program to train farmers to use management information systems designed for farms and farming groups for the nation. Over the years, such advancement has been tremendous. With the support of the project, the department started deploying faculty members to participate training programs, faculty-list to companies that design and implement the software used by agribusinesses (farms and agricultural cooperatives). The project also aims to incorporate the leaning and sharing from the agribusiness and its supporting industry to include in the traditional courses.

\section{REFERENCES}

[1] D. G. o. B. A. a. S. (. Taiwan, “Agriculture, Forestry, Fishery and Animal Husbandry Census: 2015 Statistical Analysis," 2015. [Online]. Available: https://eng.stat.gov.tw/public/Data/8612192610VTN8 S5VB.pdf. [Accessed 2017]

[2] e-Stat, "Statistics of Japan: Summary Report of 2015 Agricultural Census," Japanese Government Statistics, 2017. [Online].

[3] C. o. Agriculture, New Agricultural Innovation Promotion Plan, Taipei: Council of Agriculture, Executive Yuan, Taiwan, 2016.

[4] M. Shelman and A. J. Connolly, "The Human Capital Issue: Ensuring the Future of Food and Agribusiness," International food and agribusiness management review, vol. 15, no. A, pp. 1-4, 2012.

[5] V. Scafarto, F. Ricci and F. Scafarto, "Intellectual capital and firm performance in the global agribusiness industry," Journal of intellectual capital, vol. 17, no. 3, pp. 530-552, 2016.

[6] Y. C. Chang, C. C. Hua, H. Y. Lin, C. C. Huang, J. C. Teng and C. N. Chen, "Job skill need assessment for the next decade for the 5+2 industries," New agricultural innovation promotion plan, 2018.

[7] W. C. Huang, "Enhancing International Mobility for Students in Higher Educational Institutions: Overseas internship design and experiences for agribusiness major in Taiwan," in 2019 Taiwan-Korea Agricultural Economic Conference: Emerging Issues in Agricultural and Environment, Jeju, South Korea, 2019.

[8] N. D. Council, "2018 National Development Plan," 2017. [Online]. Available: http://ws.ndc.gov.tw. [Accessed 2019]. 